\title{
PENGARUH PENAMBAHAN TOMAT TERHADAP SIFAT FISIKOKIMIA DAN SENSORIS SELAI SEMANGKA (Citrullus vulgaris, Schrad)
}

\section{THE EFFECT OF TOMATO ADDITION TO THE PHYSICOCHEMICAL AND SENSORY PROPERTIES OF WATERMELON JAM (Citrullus vulgaris, Schrad)}

\author{
Rakhmi Habibah ${ }^{1}$, Windi Atmaka ${ }^{1)}$, Choirul Anam ${ }^{1)}$ \\ ${ }^{1)}$ Program Studi Ilmu dan Teknologi Pangan, Fakultas Pertanian, Universitas Sebelas Maret \\ Email: rakhmi.habibah@gmail.com
}

\begin{abstract}
This study aimed to determine the effect of tomato fruit's concentration addition on the physicochemical (TDS, viscosity, pH, vitamin C content, moisture content and antioxidant activity) and sensory properties of watermelon jam. The experiment design using Fully Randomized Design (FRD) with one factor, that was the treatment combination of tomato addition on watermelon fruit jam (70\%: 30\%: 65\%: 35\%, 60\%: 40\%, 55\%: 45\%, 50\%: $50 \%$ ). Statistic analysis using oneway ANOVA at $\alpha$ level of 0.05 followed by Duncan's Multiple Range test using Test (DMRT) at a level of 0.05. The addition of tomatoes at different concentrations did not affect the total dissolved solids (TDS), viscosity and sensory (color, aroma, taste, ease of topical, overalls), however effect to $\mathrm{pH}$, vitamin $\mathrm{C}$ content, moisture content, antioxidant activity and sensory (texture) of watermelon jam. The value of Watermelon jam TDS increases then decreases over the addition of tomatoes $35 \%$, while the viscosity value is almost the same in all samples. TDS value of all samples is compliant with SNI. Value of the vitamin $C$ content, moisture content and antioxidant activity increased, opposite to $p H$. The lowest $\mathrm{pH}$ value (3.79), the highest levels of vitamin C (27,64mg / 100gr), and the greatest antioxidant activity $(6.013 \%$ $\mathrm{DPPH} / \mathrm{mg}$ ) obtained from tomato Watermelon comparison 50\%: 50\%. Comparison of watermelon and tomato jam which had the highest sensory score was 60\%: $40 \%$.
\end{abstract}

Keywords: antioxidant activity, lycopene, tomato,watermelon

\section{ABSTRAK}

Penelitian ini bertujuan untuk mengetahui pengaruh penambahan konsentrasi buah tomat terhadap sifat fisikokimia (TPT, viskositas, $\mathrm{pH}$, kadar vitamin $\mathrm{C}$, kadar air dan aktivitas antioksidan ) dan sensori selai semangka. Rancangan percobaan adalah Rancangan Acak Lengkap (RAL) dengan satu faktor yaitu kombinasi perlakuan penambahan tomat pada selai buah semangka (70\%:30\%; 65\%:35\%, 60\%:40\%, 55\%:45\%, 50\%:50\%). Untuk melihat beda nyata antar perlakuan, dianalisis secara statistik menggunakan oneway ANOVA pada taraf $\alpha$ 0,05 dilanjutkan dengan menggunakan uji Duncan Multiple Range Test (DMRT) pada taraf $\alpha 0,05$. Penambahan tomat pada konsentrasi berbeda tidak berpengaruh terhadap total padatan terlarut (TPT), viskositas dan sensori (warna, aroma, rasa, kemudahan oles, overall), tetapi berpengaruh terhadap $\mathrm{pH}$, kadar vitamin $\mathrm{C}$, kadar air, aktivitas antioksidan dan sensori (tekstur) selai semangka. Nilai TPT selai semangka meningkat kemudian turun diatas penambahan tomat 35\%, sedangkan nilai viskositasnya hampir sama pada semua sampel. Nilai TPT semua sampel sudah memenuhi persyaratan SNI. Nilai pada kadar vitamin C, kadar air dan aktivitas antioksidan meningkat, berbanding terbalik dengan $\mathrm{pH}$. Nilai $\mathrm{pH}$ terendah $(3,79)$, kadar vitamin $\mathrm{C}$ tertinggi $(27,64 \mathrm{mg} / 100 \mathrm{gr})$, dan aktivitas antioksidan terbesar $(6,013 \% \mathrm{DPPH} / \mathrm{mg})$ didapatkan dari perbandingan semangka tomat 50\%:50\%. Perbandingan selai semangka dan tomat yang memiliki nilai sensori tertinggi adalah 60\%:40\%.

Kata Kunci : aktivitas antioksidan, likopen, tomat, semangka

\section{PENDAHULUAN}

Sebagian besar masyarakat Indonesia belum memanfaatkan buah semangka sebagai aneka olahan pangan sehingga selama ini buah semangka hanya dikonsumsi dalam bentuk segar. Selain itu, buah semangka dan tomat merupakan komoditas pertanian yang mudah rusak (perishable). Oleh karena itu, diperlukan diversifikasi produk olahan buah semangka. Menurut BPS (2013), produksi semangka di Indonesia mengalami peningkatan pada beberapa tahun terakhir ini.

Konsentrasi lycopene semangka adalah $4868 \mu \mathrm{g} / 100 \mathrm{~g}$ semangka segar, yang mana $40 \%$ lebih tinggi daripada konsentrasi lycopene dari tomat mentah $(3025 \mu \mathrm{g} / 100 \mathrm{~g}$ tomat). $100 \mathrm{~g}$ semangka menyediakan $8,1 \mathrm{mg}$ vitamin C dan 569 IU vitamin A. Selain itu, juga merupakan sumber yang baik vitamin $B$, terutama B1, B6 dan serta mineral seperti kalium dan magnesium (A.J. Edwards, et al, 2003, USDA, Food composition database; 
Quek, Siew Young, et al, 2007). Menurut Lembang (2012), albedo semangka tersusun atas 21,03\% senyawa pektin. Kulit buah semangka juga kaya akan vitamin, mineral, enzim, dan klorofil. Tomat yang dihancurkan atau dimasak nampaknya menjadi sumber likopen lebih baik dibanding tomat utuh, karena selama proses pemanasan tersebut terjadi isomerisasi dan oksidasi. Konsumsi tomat yang tidak dimasak tidak akan meningkatkan konsentrasi serum likopen (Sies, 1992).

Selai adalah bahan makanan yang kental atau semi padat, terbuat dari campuran 45 bagian berat buah-buahan dan 55 berat gula (Astawan dan Astawan, 1991). Tiga bahan pokok pada proses pembuatan selai adalah pektin, asam, dan gula dengan perbandingan tertentu. Asam yang umum ditambahkan dalam pembuatan selai adalah asam sitrat. Menurut Yilmaz (2000), asam organik tomat terdiri dari sekitar $15 \%$ dari berat kering tomat segar. Asam sitrat dan malat adalah asam organik utama, di samping beberapa asam karboksilat lainnya, asam gula, dan asam alisiklik.

Untuk menutupi kekurangan pektin pada selai semangka dilakukan penambahan bubur kulit putih semangka. Sedangkan penambahan tomat pada selai sebagai bahan tambahan asam dan meningkatkan nilai gizi selai semangka. Berdasarkan uraian di atas maka perlu dilakukan penelitian tentang besarnya konsentrasi tomat yang ditambahkan pada pembuatan selai semangka agar dapat diperoleh selai semangka dengan warna yang baik dan konsistensi yang baik pula.

Penentuan konsentrasi bubur kulit putih semangka yang digunakan dalam penelitian ini diperoleh dari hasil penelitian pendahuluan yaitu $30 \%$ dengan pertimbangan bahwa penambahan konsentrasi tersebut menghasilkan selai yang tidak terlalu lembek, dan tidak terlalu kaku. Walaupun demikian, selai yang dihasilkan belum diketahui karakteristik fisik, kimia, dan sensorinya sehingga perlu dilakukan penelitian lebih lanjut yang bertujuan mengetahui pengaruh penambahan kosentrasi tomat terhadap karakteristik fisik (total padatan terlarut dan viskositas), kimia $(\mathrm{pH}$, kadar vitamin C, kadar air dan aktivitas antioksidan), dan sensori (uji skoring) selai semangka.

\section{METODE PENELITIAN}

\section{Alat}

Alat yang digunakan untuk pembuatan selai semangka antara lain pisau, sendok, blender, wajan, kompor dan botol bening 250 gram. Sedangkan alat-alat yang digunakan untuk analisis sebagai berikut:

1.Kadar asam askorbat (vitamin C): timbangan analitik, alat titrasi, erlenmeyer $25 \mathrm{ml}$, gelas ukur, corong, pipet volume 1 $\mathrm{ml}$, propipet dan mikropipet.

2.Viskositas : Viskometer Ostwald

3.Total Padatan Terlarut : Refraktometer ATAGO Manual

4.Derajat keasaman $(\mathrm{pH})$ : $\mathrm{pHmeter}$

5.Kadar air: botol timbang, oven, desikator, penjepit, timbangan analitik.

6.Kadar antioksidan (DPPH): Spektrometer, tabung reaksi, propipet, pipet volume 10 $\mathrm{ml}$ dan pipet volume $5 \mathrm{ml}$

7.Sensori: nampan, pring kecil dan borang pengujian

\section{Bahan}

Bahan yang digunakan dalam penelitian ini adalah semangka Nina (Citrullus vulgaris, Schrad) dari Pasar Semangka Surakarta, tomat,gula pasir dan asam sitrat dari Pasar Gedhe Surakarta. Bahan untuk analisis antara lain aquades, larutan iodin, larutan $\mathrm{Na}_{2} \mathrm{~S}_{2} \mathrm{O}_{3}$, larutan pati $1 \%$, metanol, dan DPPH.

\section{Tahapan Penelitian}

Penelitian pendahuluan dilakukan untuk menentukan formulasi daging buah semangka dan kulit putihnya dalam bubur buah semangka (70\%:30\%, 60\%:40\%, 50\%:50\%) serta penambahan konsentrasi bubur tomat $(30 \%, 35 \%, 40 \%, 45 \%, 50 \%)$ yang akan digunakan pada penelitian utama. Proporsi daging buah semangka dan kulit putih dalam bubur buah semangka yang terpilih pada penelitian pendahuluan adalah 70\%:30\% dilihat dari tekstur dan kenampakannya. Adapun tahapan penelitian ini adalah sebagai berikut : 


\section{Persiapan Sampel}

Buah semangka yang digunakan dalam penelitian ini adalah semangka biasa jenis Nina dengan tingkat kematangan penuh. Buahnya besar, berbentuk bulat, berbiji, kulit buahnya berwarna hijau bergaris, sedangkan daging buahnya berwarna merah. Tomat yang digunakan dalam penelitian ini adalah tomat biasa atau tomat sayur atau tomat porselin. Tomat sayur atau porselin (Solanum lycopersicum 1 commune) berbuah bulat pipih, lunak, dan bentuknya tidak teratur. Tomat ini banyak dijual dipasar.

\section{Pembuatan Selai Semangka dengan Variasi Penambahan Tomat}

Pertama, buah semangka dan tomat dicuci dengan air. Buah semangka dikupas untuk diambil daging buah dan kulit putihnya dan serta dibuang bijinya. Daging buah semangka dan kulit putihnya dipotongpotong sampai dapat dilakukan pemblenderan. Tomat yang sudah dicuci, kemudian dipotong-potong. Selanjutnya diblender sampai halus kemudian disaring. Bubur semangka dan bubur tomat ditimbang sesuai dengan formulasi. Bubur buah, asam sitrat dan gula dimasak dalam wajan pada api sedang $\left( \pm 70^{\circ} \mathrm{C}\right)$. Aduk adonan sampai mengental. Titik akhir pemanasan dapat diketahui menggunakan "spoon test", dengan mencelupkan sendok ke dalam adonan, kemudian angkat, jika adonan meleleh tidak lama setelah sendok diangkat dan terpisah menjadi dua maka pemasakan telah cukup. Selanjutnya dimasukkan kedalam botol yang sebelumnya sudah disterilisasi dengan cara direbus dalam air mendidih selama 30 menit.

\section{Rancangan Percobaan}

Rancangan percobaan yang digunakan dalam penelitian ini adalah rancangan acak lengkap (RAL) dengan satu faktor yaitu kombinasi perlakuan penambahan tomat pada selai buah semangka. Masing-masing dengan 2 kali ulangan sampel, 2 kali ulangan analisis. Data hasil penelitian dianalisis menggunakan Software SPSS versi 17 untuk one way ANOVA $(\alpha=0.05)$ kemudian dilanjutkan dengan uji Duncan Multiple Range Test (DMRT) pada tingkat $\alpha=0.05$.

\section{Metode Analisis}

Pengujian yang dilakukan meliputi analisis kadar vitamin $\mathrm{C}$ dengan metode titrasi iodin (Sudarmadji dkk, 2007), kadar air dengan metode termogravimetri (Sudarmadji dkk, 2007); pH dengan pH meter (Ropiani, 2006), aktivitas antioksidan dengan metode DPPH (Subagio and Morita, 2001), viskositas dengan viskometer (Ropiani, 2006), TPT dengan refraktometer (Widyasari, 2002). Karakteristik sensori dengan metode kesukaan (Kartika dkk, 1988; Setyaningsih dkk, 2008)

\section{HASIL DAN PEMBAHASAN}

\section{A. Karakteristik Fisik Selai Buah Semangka dengan Penambahan Tomat}

Tabel 1 Sifat Fisik Selai Buah Semangka

\begin{tabular}{ccc}
\hline $\begin{array}{c}\text { Rasio } \\
\text { semangka: } \\
\text { tomat }\end{array}$ & $\begin{array}{c}\text { TPT } \\
(\% \mathrm{~b} / \mathrm{b})\end{array}$ & $\begin{array}{c}\text { Viskositas } \\
(\text { centipoise })\end{array}$ \\
\hline $70 \%: 30 \%$ & $71.10^{\mathrm{bc}}$ & $1.913778^{\mathrm{a}}$ \\
\hline $65 \%: 35 \%$ & $73.50^{\mathrm{c}}$ & $1.892163^{\mathrm{a}}$ \\
\hline $60 \%: 40 \%$ & $70.50^{\mathrm{abc}}$ & $1.913224^{\mathrm{a}}$ \\
\hline $55 \%: 45 \%$ & $67.65^{\mathrm{ab}}$ & $1.888837^{\mathrm{a}}$ \\
\hline $50 \%: 50 \%$ & $66.90^{\mathrm{a}}$ & $1.903802^{\mathrm{a}}$ \\
\hline
\end{tabular}

Keterangan: notasi yang berbeda pada kolom yang sama menunjukan beda nyata pada signifikansi $\alpha=5 \%$

\section{Total Padatan Terlarut}

Analisis total padatan terlarut bertujuan mengukur jumlah zat padat yang larut dalam air. Komponen yang terkandung dalam buah terdiri atas komponen-komponen yang larut air seperti glukosa, fruktosa, sukrosa dan pektin. Nilai TPT meningkat kemudian semakin turun dengan meningkatnya konsentrasi penambahan tomat diatas 35\%. Penyebab penurunan nilai TPT pada selai semangka adalah penurunan jumlah daging buah semangka dan juga diduga karena peningkatan jumlah buah tomat. Daging buah semangka mengandung banyak sukrosa sehingga penurunan jumlah daging buah semangka dalam formulasi selai akan menurunkan nilai TPT. Pada refraktometer, nilai indeks bias setara dengan total padatan terlarut yang dihitung sebagai konsentrasi 
sukrosa (BSN, 2008) dan dinyatakan dengan satuan ${ }^{\circ}$ Brix sukrosa.. Meskipun terjadi penurunan jumlah albedo semangka yang menjadi sumber pektin, dengan peningkatan jumlah tomat (sumber pektin) yang ditambahkan pada selai semangka menyebabkan kadar pektin berada dibatas optimalnya sehingga mempersulit kelarutan. Hidrokoloid seperti pektin dan karaginan mempunyai kemampuan mengikat air dalam jumlah besar. Seharusnya, dengan penurunan jumlah pektin dalam selai dapat meningkatkan nilai TPT karena komponen yang larut dalam air meningkat. Namun hasil penelitian yang menyatakan sebaliknya menunjukkan bahwa selain dari buah semangka pektin dalam selai bersumber dari buah tomat. Analisis sidik ragam menunjukkan bahwa penambahan tomat tidak memberikan pengaruh yang nyata terhadap nilai total padatan terlarut selai buah semangka. Semua sampel sudah sesuai dengan standar SNI-01-3746-1995 selai buah.

\section{Viskositas}

Penambahan tomat pada selai semangka tidak berpengaruh nyata pada nilai viskositas pada taraf signifikansi $\alpha 5 \%$. Nilai viskositas pada penelitian ini hampir sama pada setiap sampel karena proses pemasakan yang langsung dihentikan ketika sudah terjadi pembentukan gel. Faktor yang sangat berpengaruh terhadap keragaman viskositas akhir selai adalah proses pengolahan. Hal ini erat kaitannya dengan pengendalian pengolahan, khususnya penentuan saat penghentian proses pengentalan, tingkat panas yang digunakan saat memasak, pengadukan dan lama proses pemasakan. Sebagai perbandingan, penelitian yang dilakukan Ropiani (2006) menunjukkan nilai viskositas produk selai pepaya bangkok dengan variasi penambahan konsentrasi pektin dan natrium benzoat adalah sebesar 2,7612 cp - 5,9558 cp. Hal ini disebabkan karena pada penelitian ini pembuatan selai tanpa adanya penambahan bahan pengawet buatan yang dapat meningkatkan nilai viskositas produk selai karena penambahan pektin dan natrium benzoat menjadikan kekentalan meningkat. Glicksman (1983) menyatakan viskositas sebagai gesekan di bagian dalam suatu fluida, sehingga dipengaruhi oleh banyaknya partikel yang terkandung dalam suatu larutan dan besarnya bahan pengental yang ditambahkan akan mempengaruhi besarnya nilai viskositas. Semakin banyak jumlah partikel dan bahan pengental dalam bahan, partikel-partikel dalam bahan semakin sering bertabrakan dan menyebabkan semakin banyak pula gesekan yang terjadi dalam larutan.

\section{B. Karakteristik Kimia Selai Buah Semangka dengan Penambahan Tomat}

Tabel 2. Sifat Kimia Selai Buah Semangka

\begin{tabular}{|c|c|c|c|c|}
\hline $\begin{array}{c}\text { Rasio } \\
\text { semangka: } \\
\text { tomat }\end{array}$ & $\mathrm{pH}$ & $\begin{array}{l}\text { Vit C } \\
(\mathrm{mg} / \\
100 \mathrm{~g})\end{array}$ & $\begin{array}{l}\text { Kadar } \\
\text { Air } \\
(\%)\end{array}$ & $\begin{array}{c}\text { Akt. } \\
\text { Antioksi } \\
\text { dan } \\
\text { (\%DPPH } \\
/ \\
\mathrm{mg})\end{array}$ \\
\hline $\begin{array}{c}70 \%: \\
30 \%\end{array}$ & $\begin{array}{l}3.9 \\
08^{\text {a }}\end{array}$ & $12.093^{\mathrm{a}}$ & $23.167^{\mathrm{a}}$ & $3.279^{\mathrm{a}}$ \\
\hline $\begin{array}{c}65 \%: \\
35 \%\end{array}$ & $\begin{array}{l}3.8 \\
80^{\mathrm{b}}\end{array}$ & $14.684^{\mathrm{a}}$ & $25.029^{\mathrm{a}}$ & $3.569^{\mathrm{b}}$ \\
\hline $\begin{array}{c}60 \%: \\
40 \%\end{array}$ & $\begin{array}{l}3.8 \\
48^{\mathrm{c}} \\
\end{array}$ & $19.003^{b}$ & $25.847^{\mathrm{a}}$ & $4.346^{\mathrm{c}}$ \\
\hline $\begin{array}{c}55 \%: \\
45 \%\end{array}$ & $\begin{array}{l}3.8 \\
20^{\mathrm{d}}\end{array}$ & $26.776^{c}$ & $29.222^{\mathrm{b}}$ & $5.108^{\mathrm{d}}$ \\
\hline $\begin{array}{c}50 \%: \\
50 \%\end{array}$ & $\begin{array}{l}3.7 \\
93^{\mathrm{e}} \\
\end{array}$ & $27.640^{\mathrm{c}}$ & $28.696^{\mathrm{b}}$ & $6.013^{\mathrm{e}}$ \\
\hline
\end{tabular}

Keterangan: notasi yang berbeda pada kolom yang sama menunjukan beda nyata pada signifikansi $\alpha=5 \%$

pH

Penurunan nilai $\mathrm{pH}$ (peningkatan keasamaan) berkorelasi positif dengan semakin banyak tomat yang ditambahkan pada selai semangka. Uji statistik menunjukkan bahwa faktor penambahan tomat memberikan pengaruh nyata pada nilai $\mathrm{pH}$ selai buah semangka. Hasil uji Duncan menunjukkan bahwa terdapat perbedaan nyata antar sampel pada taraf kepercayaan $95 \%$. $\mathrm{pH}$ buah tomat segar berkisar antara 4 4,2 . Karena kandungan asam-asam organik pada tomat seperti asam sitrat dan asam malat menyebabkan tomat bersifat asam, sehingga semakin tinggi konsentrasi penambahan tomat pada selai maka $\mathrm{pH}$ selai semakin turun karena asam sitrat merupakan senyawa asidulan yang bersifat asam yang 
mampu menurunkan $\mathrm{pH}$. Ion hidrogen $\left(\mathrm{H}^{+}\right)$ yang berasal dari asam sitrat mengakibatkan koloid-koloid tersebut dinetralkan muatannya sehingga terbentuk ikatan hidrogen yang merubah bentuk rantai polimer pektin yang semula lurus menjadi bentuk tiga dimensi yang mampu menangkap air (Fachruddin, 2008). Oleh karena ion hidrogen yang digunakan untuk menetralkan muatan pektin lebih banyak, mengakibatkan kombinasi perlakuan dengan penambahan tomat yang semakin tinggi memiliki derajat keasaman/ $\mathrm{pH}$ yang semakin rendah. Menurut Collin (1940) di dalam Mark dan Stewart (1955), menyatakan penambahan asam sitrat pada konsentrasi yang cukup untuk mencapai $\mathrm{pH}$ 3,0-4,7 dapat menghasilkan gel yang halus dan membentuk gel yang cepat. Sehingga selai semangka dengan penambahan tomat pada penelitian ini sudah memenuhi kriteria dalam syarat pembentukan gel pada selai menurut Stewart (1955), namun masih berpotensi sebagai tempat tumbuhnya khamir atau kapang.

\section{Kadar Vitamin C}

Berdasarkan Tabel 2 diketahui bahwa selai dengan perbandingan semangka dan tomat 50\%:50\% memiliki kandungan vitamin C terbesar yaitu 27,64 mg/100g dan kadar vitamin terendah pada selai semangka dengan perbandingan semangka dan tomat 70\%:30\% yaitu 12,09 mg/100g. Penambahan tomat memberikan pengaruh yang nyata terhadap kadar vitamin $\mathrm{C}$ selai buah semangka. Karena sumber utama vitamin C pada selai berasal dari buah tomat. Hasil uji Duncan menunjukkan bahwa selai semangka dengan penambahan tomat $30 \%$ tidak berbeda nyata dengan selai semangka dengan penambahan $35 \%$, namun berbeda nyata dengan ketiga sampel lainnya. Selai semangka dengan penambahan tomat $40 \%$ berbeda nyata dengan semua sampel. Selai semangka dan tomat 55\%:45\% tidak berbeda nyata dengan sampel selai semangka dan tomat 50\%:50. Adanya proses pemasakan selai dapat mengakibatkan penurunan kandungan vitamin C. DeMan (1989) menyatakan vitamin $\mathrm{C}$ merupakan vitamin yang paling tidak stabil atau mudah rusak.

\section{Kadar air}

Kadar air selai semangka yang terlihat pada Tabel 2 menunjukkan kadar air yang berkisar antara 23,167\% - 28,696\%. Hasil analisa statistik menunjukkan bahwa faktor penambahan tomat memberikan pengaruh yang nyata terhadap nilai kadar air selai buah semangka. Hasil uji Duncan menunjukkan perbandingan selai semangka tomat 70\%:30\%, 65\%:35\%, dan 60\%:40\% berbeda nyata dengan selai semangka tomat 55\%:45\% dan 50\%:50\%. Gula dapat mempengaruhi kadar air pangan. Daya larut yang tinggi dari gula, kemampuan mengurangi keseimbangan kelembaban relatif $(E R H)$ dan mengikat air adalah sifatsifat yang menyebabkan gula di pakai dalam pengawetan bahan pangan (Buckle dkk, 1987).

\section{Aktivitas antioksidan}

Berdasarkan analisis statistik menunjukkan bahwa aktivitas antioksidan selai buah semangka berkolerasi positif dengan peningkatan konsentrasi tomat yang ditambahkan.Penambahan tomat memberikan pengaruh yang nyata terhadap kadar aktivitas oksidan selai buah semangka pada taraf signifikasi $\alpha 5 \%$. Hasil uji Duncan menunjukan bahwa tiap sampel berbeda nyata dengan sampel lainnya. Nilai aktivitas antioksidan terbesar yaitu $6.013 \% \mathrm{DPPH} / \mathrm{mg}$ pada selai semangka dan tomat 50\%:50\% dan nilai aktivitas antioksidan terendah pada sampel dengan selai semangka dan tomat 70\%:30\% sebesar 3,279\% DPPH/mg. Dengan kombinasi senyawa antioksidan yang dimiliki oleh buah semangka dan tomat maka selai semangka dengan penambahan tomat memiliki aktivitas antioksidan yang tinggi, sehinga kualitas senyawa fungsional selai juga akan meningkat.

Lycopene atau yang sering disebut sebagai $\alpha$-carotene adalah suatu karotenoid pigmen merah terang, suatu fitokimia yang banyak ditemukan dalam sayuran dan buah yang berwarna merah seperti tomat dan semangka. Lycopene merupakan suatu antioksidan yang sangat kuat. Kemampuannya mengendalikan singlet oxygen (oksigen dalam bentuk radikal bebas) 100 kali lebih efisien daripada vitamin $\mathrm{E}$ atau 
12500 kali dari pada gluthation (Di Mascio P et al, 1989 dalam Sunarmani dan Kun Tanti, 2008). Likopen bersifat hidrofobik kuat dan dapat mengalami degradasi melalui proses isomerisasi dan oksidasi karena cahaya, oksigen, suhu tinggi, teknik pengeringan, proses pengelupasan, penyimpanan dan asam (Shi \& Maguer, 2000). Namun likopen dalam buah tomat dapat meningkat kadarnya dengan adanya proses pemasakan. Tomat merupakan sayuran yang kaya akan berbagai senyawa antioksidan seperti likopen, alfakaroten, betakaroten, lutein, vitamin $\mathrm{C}$, flavonoid dan vitamin E (Willcox, Catignani dan Lazarus, 2003). Tomat yang dihancurkan atau dimasak nampaknya menjadi sumber likopen lebih baik dibanding tomat utuh, karena selama proses pemanasan tersebut terjadi isomerisasi dan oksidasi. Konsumsi tomat yang tidak dimasak tidak akan meningkatkan konsentrasi serum likopen (Sies, 1992).

\section{Sifat Sensori Selai Buah Semangka dengan Penambahan Tomat}

\section{Warna}

Warna adalah atribut mutu yang pertama kali dinilai dalam penerimaan suatu makanan. Menurut Kartika (1988), warna merupakan suatu sifat bahan yang dianggap berasal dari penyebaran spektrum sinar, selain itu warna bukan merupakan suatu zat atau benda melainkan suatu sensasi seseorang oleh karena adanya rangsangan dari seberkas energi radiasi yang jatuh ke indera mata atau retina mata. Dari hasil uji statistik menunjukkan bahwa perlakuan penambahan tomat terhadap penerimaan panelis parameter warna tidak berpengaruh nyata dengan nilai organoleptik berkisar 3,17-3,63. Sampel dengan perbandingan semangka dan tomat 60\%:40\% merupakan sampel yang paling disukai panelis. Proses pemasakan pada selai dapat mempengaruhi warna selai yang dihasilkan. Adanya proses pemanasan menjadikan warna selai lebih pekat sehingga menjadikan selai semangka dengan penambahan tomat berwarna merah tua dan semakin tinggi persentase penambahan tomat pada selai, warna produk menjadi merah kejinggaan.

\section{Aroma}

Tabel 3 menunjukkan bahwa semua perlakuan pada sampel selai buah semangka dengan penambahan tomat tidak memberikan pengaruh yang nyata terhadap penerimaan panelis pada paramater aroma. Nilai organoleptik selai semangka berdasarkan parameter aroma berkisar antara 3,00-3,53.

\section{Rasa}

Kartika, dkk (1988) menyatakan bahwa rasa dari suatu makanan merupakan gabungan dari berbagai macam rasa bahanbahan yang digunakan dalam makanan tersebut. Tabel 3 menunjukkan bahwa nilai organoleptik rasa selai buah semangka dengan penambahan tomat berkisar antara 3,36-3,73. Hasil uji skoring rasa selai buah semangka dengan penambahan tomat menunjukkan tidak berbeda nyata diantara kelima sampel.

\section{Kemudahan Oles}

Kemudahan oles selai yang baik, maka akan semakin mudah untuk dapat diterima konsumen. Kemudahan oles dinilai dengan mengoleskan selai pada roti tawar. Tabel 3 menunjukkan bahwa nilai organoleptik pada parameter kemudahan oles ini berkisar antara 3,10-3,80. Hasil uji statistik menunjukkan bahwa penambahan tomat tidak berpengaruh nyata pada parameter kemudahan oles selai semangka. Pada sampel dengan perbandingan semangka dan tomat 60\%:40\% memiliki nilai tertinggi dibandingkan sampel lain meskipun tidak signifikan.

\section{Tekstur}

Tekstur merupakan sensasi tekanan yang dapat diamati dengan mulut (pada waktu digigit, dikunyah dan ditelan) ataupun perabaan dengan jari. Tekstur akan mempengaruhi penilaian terhadap diterima atau tidaknya produk tersebut (Kartika, 1988). Tabel 3 menunjukkan bahwa nilai organoleptik panelis terhadap parameter tekstur berkisar antara 2,60-3,53. Pada sampel dengan perbandingan semangka dan tomat 70\%:30\%, 60\%:40\% dan 50\%:50\% berbeda nyata dengan sampel dengan perbandingan semangka dan tomat 65\%:35\%. 
Tabel 3 Hasil Uji Kesukaan Selai Buah Semangka

\begin{tabular}{ccccccc}
\hline $\begin{array}{c}\text { Rasio } \\
\text { semangka: tomat }\end{array}$ & Warna & Aroma & Rasa & $\begin{array}{c}\text { Kemudahan } \\
\text { oles }\end{array}$ & Tekstur & Overall \\
\hline $70 \%: 30 \%$ & $3,53^{\mathrm{a}}$ & $3,10^{\mathrm{a}}$ & $3,36^{\mathrm{a}}$ & $3,10^{\mathrm{a}}$ & $3,53^{\mathrm{b}}$ & $3,43^{\mathrm{ab}}$ \\
\hline $65 \%: 35 \%$ & $3,27^{\mathrm{a}}$ & $3,00^{\mathrm{a}}$ & $3,26^{\mathrm{a}}$ & $3,13^{\mathrm{a}}$ & $2,60^{\mathrm{a}}$ & $3,16^{\mathrm{a}}$ \\
\hline $60 \%: 40 \%$ & $3,63^{\mathrm{a}}$ & $3,53^{\mathrm{a}}$ & $3,73^{\mathrm{a}}$ & $3,80^{\mathrm{ab}}$ & $3,53^{\mathrm{b}}$ & $3,80^{\mathrm{b}}$ \\
\hline $55 \%: 45 \%$ & $3,47^{\mathrm{a}}$ & $3,20^{\mathrm{a}}$ & $3,43^{\mathrm{a}}$ & $3,40^{\mathrm{ab}}$ & $3,03^{\mathrm{ab}}$ & $3,27^{\mathrm{a}}$ \\
\hline $50 \%: 50 \%$ & $3,17^{\mathrm{a}}$ & $3,13^{\mathrm{a}}$ & $3,43^{\mathrm{a}}$ & $3,43^{\mathrm{b}}$ & $3,40^{\mathrm{b}}$ & $3,47^{\mathrm{ab}}$ \\
\hline
\end{tabular}

Keterangan : notasi yang berbeda pada kolom yang sama menunjukan beda nyata pada signifikansi $\alpha=5 \%$ $1=$ tidak suka; $2=$ agak tidak suka; $3=$ agak suka; $4=$ suka; $5=$ sangat suka

Sampel dengan perbandingan semangka dan tomat 55\%:45\% menunjukkan hasil yang tidak berbeda nyata dengan keempat sampel lain terhadap penerimaan panelis dari parameter tekstur.

\section{Overall}

Nilai overall dalam penilaian ini bermaksud mengarah ke warna, aroma, rasa, kemudahan oles dan tekstur yang paling disukai oleh panelis sehingga dapat diketahui konsentrasi penambahan tomat yang terbaik dan disukai panelis untuk selai buah semangka. Nilai organoleptik panelis terhadap parameter overall berkisar antara 3,1-3,80. Hasil uji statistik menunjukkan bahwa penambahan tomat tidak berpengaruh nyata pada parameter overall selai semangka. Nilai tertinggi terdapat pada sampel dengan perbandingan semangka dan tomat 60\%:40\%. Dapat disimpulkan bahwa penggunaan variasi penambahan tomat dalam selai buah semangka mempunyai efek kesukaan positif karena tomat bermanfaat dalam meningkatkan kualitas tekstur dalam selai. Penerimaan overall konsumen pada penambahan tomat $45 \%$ dan $50 \%$ mengalami penurunan, namun tidak signifikan.

Untuk menentukan penambahan konsentrasi tomat yang terbaik pada selai semangka tidak dapat ditentukan hanya dengan parameter sensoris, namun perlu mempertimbangakan sifat fisikokimianya. Jika dilihat dari sifat fisikomia dan sensoris dari semua sampel maka sampel selai dengan perbandingan semangka tomat 50\%:50\% merupakan sampel terbaik dikarenakan memiliki kandungan vitamin $\mathrm{C}$ dan aktivitas antioksidan yang tertinggi serta bisa diterima konsumen.

\section{KESIMPULAN}

Berdasarkan hasil penelitian yang telah dilakukan, dapat diambil kesimpulan sebagai berikut :

1. Penambahan tomat pada selai buah semangka tidak berpengaruh signifikan terhadap nilai total padatan terlarut (TPT) dan viskositas dengan nilai TPT berkisar antara 66,90-73,50 \% dan viskositas $1,889-1,914 \mathrm{cp}$.

2. Penambahan tomat pada selai buah semangka berpengaruh signifikan terhadap nilai $\mathrm{pH}$, kadar vitamin $\mathrm{C}$, kadar air dan aktivitas antioksidan dengan nilai $\mathrm{pH}$ 3,793-3,908, vitamin C 12,093 mg/100gr27,64 mg/100gr, kadar air 23,167$29,222 \%$ dan aktivitas antioksidan 3,279 $\% \mathrm{DPPH} / \mathrm{mg}-6,013 \%$ DPPH/mg.

3. Penambahan tomat pada selai buah semangka tidak berpengaruh signifikan terhadap sensori kecuali pada parameter tekstur. Skor tertinggi pada parameter warna, aroma, rasa, kemudahan oles, tekstur, dan overall adalah sampel dengan perbandingan semangka dan tomat 60\%:40\%. Sedangkan pada parameter tekstur, nilainya sama dengan sampel selai semangka dengan perbandingan semangka dan tomat 70\%:30\%. Namun perbandingan semangka dan tomat terbaik pada selai dilihat dari sifat sensori dan fisikokimianya adalah 50\%: 50\%.

\section{SARAN}

Berdasarkan penelitian sifat fisikokimia dan sifat sensori selai buah semangka dengan penambahan tomat yang telah dilakukan, selai buah semangka perlu dikembangkan untuk dikomersialkan, 
terutama dilihat dari sifat sensorinya. Selain itu perlu dilakukan penelitian lebih lanjut terhadap umur simpan selai buah semangka.

\section{DAFTAR PUSTAKA}

Agarwal S, Rao AV. 2000. Role of Antioxidant Lycopene in Cancer and Heart Diseases. Journal of the American College of Nutrition, Vol. 19, No. 5, 563-569

Askar, A. Dan H. Treptow. 1993. Quality Assurance in Tropical Fruit Processing Springer Laboratory. Germany.

Astawan dan M.W.Astawan, 1991. Teknologi Pengolahan Pangan Nabati Tepat Guna. Akademika Pressindo. Jakarta.

Badan Pusat Statistik Republik Indonesia, 2013. Produksi Sayuran di Indonesia. www.bsn.go.id. diakses pada tanggal 14 Maret 2013 pukul 12.05 WIB.

Bohm V, Puspitasari-Nienaber NL, Ferruzi MG \& Schwart SJ. 2002. Trolox Equivalent Antioxidant Capacity of Different Geometrical Isomer of $B$ carotene, A-carotene, Lycopene and Zeaxanthin. J Agric. Food Chem, 50, 221-226

Buckle, K.A.,R.A. Edwards, G.H. Fleet and M. Wooton.1987.Ilmu Pangan. UI Press. Jakarta

DeMan JM. 1989. Kimia Makanan. Padmawinata K, penerjemah. Penerbit ITB. Bandung .

Fachrudin, L. 2008. Teknologi Tepat Guna Membuat Aneka Selai. Kanisius. Yogyakarta

Fennema, O.R. 1985. Food Chemistry. Second Edition. Marcel Dekker, Inc. USA.

Glicksman, M. 1969. Gum Technology In Food Industri. Academic Press New York Professional. London.

Johnson, J. T., Lennox, J.A., Ujong, U.P., Odey, M.O., Fila, W.O.Edem, P.N., Dasofunjo, K. 2013. Comparative Vitamins Content of Pulp, Seed and Rind of Fresh and Dried Watermelon
(Citrullus Lanatus). International Journal of Science and Technology Volume 2 No. 1: 99-103

Kartika, Bambang, Pudji Hastuti dan Wahyu Supartono. 1988. Pedoman Uji Inderawi Bahan Pangan. UGM Press. Yogyakarta.

Lembang, Evi Pania. 2012. Variasi Waktu Dan Suhu Ekstraksi Albedo Semangka (Citrullus vulgaris Schard.) Terhadap Kualitas Permen Jelly [Skripsi]. Yoyakarta :Universitas Atma Jaya

Lorenz, O.A.,and D.N. Maynard. 1988. Knott's Handbook for Vegetable Growers. 3rd cd., John Wiley \& Sons. New York.

Mohamad, Souad Abati, Jamal, P. and Olorunnisola, K. S. 2012. Effective Jam Preparations from Watermelon Waste. International Food Research Journal 19(4): $1545-1549$

Quek, Siew Young, Ngan King Chok, Peter Swedlund. 2007.The Physicochemical Properties Of Spray-Dried Watermelon Powders. Chemical Engineering and Processing: Process Intensification Volume 46, Issue 5, Pages 386-392

Ropiani, 2006. Karakterisasi Fisik dan pH Selai Buah Pepaya Bangkok [Skipsi]. Bogor: Institut Pertanian Bogor.

Rukmana, 1994. Budidaya Semangka Hibrida. Kanisius Yogyakarta

Shi, J., \& Le Maguer M. 2000. Lycopene in Tomatoes: chemical and physical properties affected by food processing. $\mathrm{J}$. Biotech 20 (4):293-334

Sies H. 1992. Antioxidant Functions of Vitamin: vitamins $E$ and $C, A$-carotene and Other Carotenoids. Ann N Y Acad. $\mathrm{Ci}, 69,7-20$.

Silalahi, J. 2006. Makanan Fungsional. Yogyakarta: Kanisius. Hal. 40, 47, dan 48

Subagio, A and N. Morita. 2001. No Effect of Esterification with Fatty Acid on Antioxidant Activity of Lutein. Food Rest.Int. 34:315-320. 
Sudarmadji, Slamet, Bambang H., Suhardi. 2007. Analisa Bahan Makanan dan Pertanian. Liberty. Yogyakarta

Sunarmani dan Kun Tanti. 2008. Parameter Likopen Dalam Standarisasi Konsentrat Buah Tomat. Penelitian Balai Besar Penelitian dan Pengembangan Pascapanen Pertanian,

Sunarni, T. 2005. Aktivitas Antioksidan Penangkap Radikal Bebas Beberapa Kecambah dari Biji Tanaman Familia Papilionaceae. Jurnal Farmasi Indonesia 2 (2), 2001, 53-61.

Widyasari, Yessie. 2002. Karakterisasi Fisik dan Kimia Beberapa Jenis Air Minum dalam Air Kemasan dan Air Minum dari PDAM [Skripsi]. Bogor: Institut Pertanian Bogor.

Willcox JK, Catignani GL \& Lazarus S. 2003. Tomatoes and Cardiovascular Health. Critical Rev. in Food Sci and Nut, 43 (1),1-18.

Yilmaz, E. 2001. The Chemistry of Fresh Tomato Flavor. Turk J Agric For 25: 149-1 